\title{
Chagas Disease, from Discovery to Control - and Beyond: History, Myths and Lessons to Take Home
}

\author{
Carlos M Morel
}

\begin{abstract}
UNDP/World Bank/WHO Special Programme for Research and Training in Tropical Diseases (TDR), World Health Organization, 20, Av. Appia, CH-1211 Geneva 27, Switzerland
\end{abstract}

Key words: Chagas disease - discovery - research and development - control

There is a sad dissociation between the crucial role that research plays in improving health and the general lack of recognition of its role, importance and priority in public health policies. We tend to forget how much we owe to research once a success story in disease control achieves a happy end. Health authorities and policy makers use to say that they want the real thing - in other words, disease control, now - and not lose time and money with unnecessary and odd expenses - in other terms, health research for tomorrow.

Therefore, I decided to choose as the subject of my lecture a success story in disease control in South America and to point out to the role research has played along its development. It starts at the very beginning - the discovery of the disease and goes until the most recent chapter - its elimination as a major public health problem in large regions of the Southern Cone countries. Although no one can yet assure a final "happy end" to this story, progress in its control has been very successful, to the point that the World Health Organization calls it a disease whose days are numbered (Division of Control of Tropical Diseases, 1996). It is a long story - 90 years of history - that illustrates the fundamental importance of research in improving health. By analyzing it, studying the actors, the personalities, the facts, the true or false stories - in other words, the myths -, I think we can derive some universal notions and also some lessons to take home, to keep in mind and put into use when time and opportunity comes.

It is a real story, about Chagas disease - from its discovery in 1909 by the Brazilian scientist Carlos Chagas working at the Oswaldo Cruz Insti-

This paper was adapted from the 1997 Benjamin Osuntokun Memorial Lecture, The Advisory Committee on Health Research, World Health Organization, Geneva.

Fax: +41-22-791.4854. E-mail: morelc@who.int

Received 9 June 1999

Accepted 9 August 1999 tute in Rio de Janeiro to its successful control in the large regions of the Southern Cone countries in the 90s.

\section{THE INCREDIBLE - AND IMPROBABLE - DISCOVERY}

The discovery of American trypanosomiasis by Carlos Chagas has been described and reviewed in a number of publications in Portuguese (Dias 1918, Aragão 1950, Da Fonseca filho 1973, Brener 1989, Chagas Filho 1993, Delaporte 1995, Coura 1997) and English (Guerra 1970, Lewinsohn 1979, Wendel \& Brener 1992, Miles 1996, Perleth 1997). However, it is only by reading the original articles of Chagas himself [a magnificent collection of all the papers published by Carlos Chagas was organized by Prof. A Prata and published in 1981 by the University of Brasilia (Prata, 1981)] particularly his classical paper on "Ueber eine neue Trypanosomiasis des Menschen", published in Portuguese and German in the first volume of the Memórias do Instituto Oswaldo Cruz in August, 1909 (Chagas 1909) that one can fully apprehend the quality, the extension and the impact of the work of that 29-year old researcher. His genius enabled him to describe the agent, vectors, clinical signs in human beings, animals and the existence of animal reservoirs of a new disease. In this paper, which has superb color plates, Chagas describes the human infection, the parasite (then known as Schizotrypanum cruzi), the cycle in the digestive tract of the invertebrate vector, cultivation in agar-blood and transmission to vertebrates of flagellates from infected triatomines (Wendel \& Brener 1992).

How could one of the major medical discoveries happen in a poor country in the tropics, be published on the first volume of a local institutional journal and yet receive world-wide recognition and be one of the seeds of a whole school of thought and research which still today has such a profound influence in Latin American science?

The roots of this breakthrough have to be analyzed in conjunction with the role played by Oswaldo Cruz and the institution created by the Brazilian Government in 25 May 1900 to fight endemic diseases and which bears his name since 
1908. This extrapolates the aim of this presentation and I have no choice but to limit myself just to cite some key references (Da Fonseca filho 1973, Stepan 1976) and point to some of the major factors contributing to this "miracle":

- Oswaldo Cruz spent some time at the Pasteur Institute in Paris, and was convinced that the Pasteurian philosophy of combining strategic research, development, production (e.g. of sera and vaccines) and education of young researchers in a single institution would be the key to success; in contemporary words, he was a firm believer in a scientific research system (Stepan 1976);

- by propagating the role that science should play in the development of Brazil, Oswaldo Cruz managed to conquer and receive support from the highest political level (President Rodrigues Alves); being nominated Director of the Federal Department of Public Health, he could efficiently fight the diseases that were devastating Brazil's economy, particularly yellow fever and plague;

- having acquired national leadership, he could mobilize the funds for building up a first-class institution, whose main building - a Moorishstyle palace, based on original drawings by Oswaldo Cruz himself, inspired on the Observatoire Météorologique de Montsouris in Paris - still today attract the curiosity of the lay person, facilitating another of his primary goals: legitimizing the role of science in society;

- very early in the life of the Institute, after his first successes against yellow fever epidemics which brought to the Institute the Golden Medal of the XII International Hygiene Conference in Berlin in 1907 -, Oswaldo Cruz could attract the collaboration of scientists from developed countries, particularly from Germany, who would come to visit and work in Rio de Janeiro, interacting with the team of young Brazilian students and researchers recruited to work at the Institute (Gustav Giemsa, Stanislas von Prowazek, Max Hartmann, among others);

- the access to information was always a priority to Oswaldo Cruz; with the funds he could raise, either directly from the government or through the selling of sera and vaccines, he started to build up a very complete biomedical library, acquiring whole collections of contemporary periodicals, some of them dating back to the 18th century. In 1911 the library had already more than 10,000 volumes, making it the largest specialized collection in South America (Stepan 1976).

With the premature death of Oswaldo Cruz in 1917, when he was only 45 years old, Carlos Chagas became Director of the Institute. This position he kept until his death in 1934 at the age of 55. Already recognized as a great scientist, he was able to keep the national and international prestige and recognition needed for the consolidation of a genuine Brazilian school of tropical medicine, the "Escola de Manguinhos" [Manguinhos (= little mangrove) was the name of the farm where the Institute was built] (Da Fonseca filho 1973).

Ninety years later, when we are still discussing the role and the place of health research in development (Comission on Health Research for Development 1990, Task Force on Health Research for Development 1991, Davies \& Mansourian 1992, Godal et al. 1996, Raymond 1997), it is surprising to note how many of the principles and factors underlying today's proposed policies and strategies were already present in a poor country in the beginning of the century.

Lesson to take home, \#1 - The "impossible" can happen - do not underestimate the potential and the capacity of developing countries to identify and manage their own health problems.

\section{UNVEILING THE DISEASE}

Owing to his discovery, Carlos Chagas received several prizes, honorary degrees and distinctions (Extraordinary Member, Brazilian Academy of Medicine; Schaudinn Prize, awarded every four years to the best work in Parasitology and Tropical Medicine in the world, Tropical Diseases Institute of Hamburg; Great Prize of the Pasteur Centenary Commemorative Exposition in Strasbourg, 1922, among others). This success provoked open opposition, which culminated in 1916 with the denial of his findings by Rudolf Kraus, one of the most prominent German microbiologists, during the 1st Pan-American Congress in Buenos Aires, with the argument that he had been unable to find cases of Chagas disease in the Argentine Chaco (Kraus et al. 1915, Kraus \& Rosenbusch 1919). As Chagas had also strong opposition in the Brazilian National Academy of Medicine this episode had a devastating effect and Chagas disease was forgotten for almost 20 years (Wendel \& Brener 1992). According to some researchers Kraus may have been right because Chagas disease would have spread in the Argentine Chaco only some years later (Schofield, pers. comm. and Schofield \& Dias 1996).

The "resurrection" of Chagas disease is mainly due to the work of Salvador Mazza in Argentina, who described more than a thousand cases particularly in regions which Kraus had studied 20 years before (Mazza 1934, 1936). Mazza was also the first one to raise the possibility of transfusion- transmitted Chagas disease (Mazza et al. 1936).

However, it was not until the 80s that countrywide surveys were conducted using standardized protocols and the overall prevalence of human Try- 
panosoma cruzi infection could be reliably estimated: 18 million cases in 21 endemic countries, with 100 million people $-25 \%$ of all the inhabitants of Latin America - at risk of infection (Division of Control of Tropical Diseases 1996). The burden of the disease, measured in DALYs and according to data from the World Bank in 1993, showed that in Latin America Chagas disease ranks 1 st among the tropical diseases, and 4th among the transmissible diseases, only behind acute respiratory infections, diarrhoeal disease and Aids (Schmunis 1997).

Why did it take so long to fully disclose the extent of this scourge, if Carlos Chagas in his early papers already called the attention to the social, economic and public health relevance of the disease he had discovered? Was it lack of scientific evidence?

Not so simple, it seems. In this long period almost 80 years, from discovery to the large-scale mapping of its prevalence and social impact in the American continent - important information was in fact building up continuously as the result of laboratory, clinical, epidemiological, socioeconomic and applied field research studies. A detailed description of the major findings is again beyond the scope of this lecture. Table I is meant as an initial guide to those interested in further readings. However their results did not translate easily into action. The analysis of the reasons why this did not happen points to the fact that the disease affects mainly poor rural areas that traditionally receive little or no political priority (Dias 1987), and shows how deep can be the gap among researchers, decision makers, politicians and public interest.

Lesson to take home, \#2 - Solid research findings and sound scientific evidence alone, are not sufficient for establishing or imposing political priorities.

TRANSFORMING RESEARCH INTO ACTION, RESEARCHERS INTO POLICY-MAKERS (OR: THE SUCCESSFUL MOBILIZATION TOWARDS CONTROL)

As knowledge about the disease and its prevalence increased, a small group of researchers working at the now legendary Bambuí field station of the Oswaldo Cruz Institute in the State of Minas Gerais, was slowly coming out with the notion that Chagas disease, unlike many other parasitic diseases, could be controlled by eliminating vector populations, chiefly by using insecticides and housing improvements (Dias 1987).

The crucial experiments were the field trials conducted by Dias and Pellegrino in Brazil and Romaña and Abalos in Argentina in 1947 showing the efficacy of organochlorine insecticides against domiciliated triatomine bugs (Dias \& Pellegrino 1948, Romaña \& Abalos 1948,
Schofield 1994). So good were the results, in fact, that a telegram was sent to the Brazilian Ministry of Health, suggesting that Chagas disease transmission could be eliminated throughout the territory (Dias \& Pellegrino 1948, Pellegrino 1953, Silveira \& Rezende 1994, Miles 1996).

Again, was this discovery powerful enough to mobilize the political forces of the nation? Not at all. In spite of the heavy burden of the disease and of the proven availability of appropriate technology for fighting its vectorial transmission, only isolated actions were taken between 1950 and 1975 (Silveira \& Rezende 1994).

All that changed in the 90s, when political decisions at the highest level in six countries established the so-called Southern Cone Initiative - and what we saw in the following years already deserves a special place in history. How and why did that happen? Which were the forces that promoted such a radical change? Which were the major factors responsible for this major shift in priority?

A scientific answer to these questions is surely to be looked for by social scientists, not by a molecular biologist such as myself. Therefore, what follows is just a very personal view of a curious observer and a participating scientist. It may simply be a myth. But as in some cultures a myth is just another way of telling a true story, why not share it with you today?

In 1974 the National Research Council of Brazil (CNPq), which had just started its successful "Integrated Programme on Endemic Diseases" (Programa Integrado de Doenças Endêmicas, PIDE), organized a very small meeting at its headquarters in Rio de Janeiro, with less than ten participants, to discuss some problems in the study of $T$. cruzi. One important issue of the meeting was the development of a common protocol to cultivate better this parasite in the laboratory. After this was agreed upon, the idea came to organize a second meeting, in one year's time, to evaluate progress made. Prof. Zigman Brener, of the "René Rachou" Regional Research Center of Fiocruz in Belo Horizonte, State of Minas Gerais, was selected by the participants themselves as the organizer of the next meeting.

Owing to the limited $\mathrm{CNPq}$ facilities at that time in Rio de Janeiro and also to the fact that the interested participants were working in Rio, São Paulo and Belo Horizonte - and surely because Zigman Brener is from Minas Gerais - the second meeting was arranged to take place in the city of Caxambu, State of Minas Gerais, which is sort of equidistant from those three cities, therefore facilitating travel by car or bus and reducing the costs. In this way the 2nd Annual Meeting on Basic Research on Chagas Disease was organized in November 1975. Although the scientific progress had been solid in 


\section{TABLE I}

Selected dates in Chagas disease research and development (R\&D) and control

Date
1872, August 25: Oswaldo Cruz is born
in São Luis de Paraitinga, State of São
Paulo, Brazil

1878, July 9: Carlos Chagas is born in Oliveira, State of Minas Gerais, Brazil

1892: Oswaldo Cruz gets his MD degree at the Medical Faculty of Rio de Janeiro, at the age of 20

1896-1899: training of Oswaldo Cruz at the Pasteur Institute, Paris

1900, May 25: creation of the "Instituto Soroterápico Federal de Manguinhos"

1904: Carlos Chagas gets his MD degree at the Medical Faculty of Rio de Janeiro, at the age of 25

1907: the "Instituto de Patologia Experimental de Manguinhos" receives the Golden Medal at the International Hygiene Exhibition in Berlin

1909: discovery of Trypanosoma cruzi and Chagas disease; publication of the 1st volume of the "Memórias do Instituto Oswaldo Cruz"

1911: Gaspar Vianna describes nerve cell lesions in the acute phase of infection

1911-1913: expeditions conducted by the Oswaldo Cruz Institute Scientists to the Brazilian hinterland

1913: complement fixation tests for Chagas disease

1914: introduction of xenodiagnosis

1916: Rudolf Kraus, one of the most prominent German microbiologists, denies Carlos Chagas findings

Comments

Refs

(Stepan 1976)

(Chagas Filho 1993)

(Stepan 1976)

(Stepan 1976)

This name changed to "Instituto de Patologia Experimental de Manguinhos" (1906), "Instituto Oswaldo Cruz" (1908), "Fundação Oswaldo Cruz (Fiocruz)" (1970)

(Stepan 1976) (Benchimol 1990) (Benchimol \& Teixeira 1993)

(Chagas Filho 1993)

(Stepan 1976)

This first volume of the Memórias contains the classical paper on the discovery of Chagas disease

(Chagas 1909)

(Vianna 1911, Thielen et al. 1991, Santos et al. 1996)

The "Machado \& Guerreiro" test

(Guerreiro \& Machado 1913)

Joseph Emile Brumpt (1877-1951)

(Brumpt 1914)

Chagas disease is forgotten for almost 20 years

(Kraus et al. 1915, Kraus \& Rosenbusch 1919, Da

Fonseca filho 1973, Wendel \& Brener 1992)

1917, February 11: death of Oswaldo Cruz, at the age of 45 in Petrópolis, State of Rio de Janeiro

1934, November 9: death of Carlos Chagas, at the age of 55 in Rio de Janeiro

1936: Mazza first raises the possibility of transfusion-transmitted Chagas disease

1941-1958: Margarino Torres studies the pathogeny of cardiac lesions in Chagas disease and proposes that "allergic reactions" might be involved

Perhaps a first observation related to the role of autoimmune mechanisms in the pathogenesis of the disease 


$\frac{\text { Date }}{\text { 1943, November: by initiative of Aragão, }}$
then the Director of the Oswaldo Cruz Institute, creation of the legendary Centro de Estudos e Profilaxia da Moléstia de Chagas, a field station of the Oswaldo Cruz Institute in Bambuí, State of Minas Gerais, Brazil

1948: first field trials of a "new insecticide" The results stimulate the "Serviço (gammexane) establish the basis for the Nacional de Malaria" to conduct chemical control of domiciliated triatomine vectors

1950: creation of the first National Control Programmes in Brazil and Argentina

1951, January 15: creation of CNPq; July 11: creation of Capes

1953: gentian violet is proposed as a chemoprophylatic agent against transfusion-transmitted Chagas disease

1955-1956: Köberle and others confirm that Chagas disease also affect the peripheral, autonomic and enteric nerves and establish the relationship between the denervation process and the disease's anatomic and functional aspects for the hollow organs of the digestive system and the urinary tract

1961: Berenice, the first patient identified to have Chagas disease, is found alive at the age of 53 and is extensively studied in Belo Horizonte, State of Minas Gerais

1974: first meeting on Basic Research in Chagas Disease, in Caxambu, MG, Brazil; creation of Pide (Integrated Programme on Endemic Diseases) in Brazil

1975: proposition of the role of autoimmunity in the pathogenesis of Chagas disease

1975: creation of the UNDP/World Bank/ WHO Special Programme for Research and Training in Tropical Diseases, TDR

1975-1980: conduction of national serologic and entomological surveys in Brazil

\section{Comments}

Refs

The creation of the Bambuí represents (Pellegrino 1953, Dias the first step towards the establishment 1986, Silveira \& Rezende of long-term clinical and applied field research in Chagas disease 1994) the first "prophylactic campaigns" against Chagas disease in 1950

Triatomine control starts in the states of Minas Gerais and São Paulo, in Brazil, and in the provinces of Chaco, La Rioja and Catamarca in Argentina

CNPq and Capes are two of the most important Brazilian S\&T agencies and played a decisive role in supporting $\mathrm{R} \& \mathrm{D}$ and training of human resources in Chagas disease

One of the first steps towards the control of blood banks

Starting 1986 the Proceedings of the Annual Caxambu Meetings are published in the Memórias do Instituto Oswaldo Cruz

Immunological and molecular data will later on support this proposition, but also rescue the importance of the continuous presence of the parasite in the pathogenesis of the disease

Strengthening of basic and applied R\&D activities;

training of endemic country scientists and development of critical mass of researchers working in Chagas disease control

Production of the first reliable data on prevalence of human infection and vector distribution
(Dias \& Pellegrin 1948,

Romaña \& Abalos 1948)

(Silveira \& Rezende 1994)

(Nussenzweig et al. 1953)

(Köberle \& Nador 1955 , Köberle 1956, Lázzari 1994)

(Salgado et al. 1962, Delana et al. 1996)

(Teixeira et al. 1975)

(Cunha-Neto et al. 1995)

(Camargo et al. 1984)

(Silveira \& Rezende 1994) 


\begin{tabular}{ccc}
\hline Date & Comments & Refs
\end{tabular}

1977-1979: Chagas disease control becomes a national priority in Brazil

1977-1980: biochemical strain characterisation of $T$. cruzi strains; description of "polar" strains

1979: a simple, common epidemiological methodology agreed to be used throughout Latin America to map Chagas disease and to quantify its prevalence

1980-1985: standardization of serological techniques and criteria for diagnosis of human T. cruzi infection and Chagas disease

1982: large scale field trials of alternative insecticides and formulations for the control of triatomine vectors

1983: Chagas disease control programmes expanded to all infected areas in Brazil; National Chagas Disease Control Programme of Uruguay reorganized

1984: Deane and collaborators demonstrate that the vertebrate and invertebrate cycles of $T$. cruzi can coexist in the same mammal host, the opossum Didelphis marsupialis; collapse of Brazil's Pide Programme

1986: first genes of T. cruzi cloned

1990: multicentre double blind study for evaluation of $T$. cruzi defined antigens as diagnostic reagents; fumigant canisters released to the market by Sintyal, Argentina

1991: at a landmark meeting in Brasília, the Ministers of Health of the Southern Cone countries (Argentina, Bolivia, Brazil, Chile, Paraguay and Uruguay) adopt a resolution calling for action to eradicate Triatoma infestans;

insecticidal paints released to the market by Iharabras, Brazil

1991-1995: industrial production of insecticide paints, fumigant canisters and triatomine sensor/detector boxes in Brazil and Argentina

1995: TDR meeting on the elimination of four diseases as public health problems (filariasis, onchocerciasis,

Isoenzymes patterns (zymodemes); restriction fingerprinting of kinetoplast DNA (schizodemes)

(Miles et al. 1977, Mattei et al. 1977, Morel et al. 1980)

(Mello \& Brener 1978)

TDR Expert Meeting in Brasília, DF, Brazil

Epidemiological cross-sectional studies using the standardised protocols

Replacement of chlorinated insecticides (Silveira 1985, Oliveira by synthetic pyrethroids; better residual Filho 1988) effect and acceptance, lower mammalian toxicity and better cost-effectiveness

(Silveira \& Rezende 1994)

The opossum, being able to harbour T. cruzi metacyclics in the scent/anal glands, can act as a direct route of infection by expelling infective forms as an aerosol

Selection of better antigens which will form the basis of the commercial production of kits in endemic countries for blood bank control

US\$ 90 million are allocated for vector control and US\$ 6 million for blood bank screening; the Initiative of the Southern Cone countries is thus born, covering an area six times larger than that covered by the West African OCP; a total of US\$ 206 million is allocated from national sources of the six countries for control operations; it is estimated that this investment will reduce the economic loss due to Chagas disease by US\$ 4550 million

Increased efficiency of control programmes and cheaper surveillance phase

A long road since the discovery of the disease and the creation of the Bambuí field station
(Deane et al. 1984, Lenzi et al. 1984, Jansen et al. 1997)

(Peterson et al. 1986)

(Moncayo \& Luquetti 1990)

(Anonymous 1995)

(Kingman 1991, Anonymous 1995, 1997)

(Anonymous 1995)

(Anonymous 1995, Zingales et al. 1997a,b) 


\begin{tabular}{|c|c|c|}
\hline Date & Comments & Refs \\
\hline \multicolumn{3}{|l|}{$\begin{array}{l}\text { leprosy and Chagas); } \\
\text { T. cruzi genome project launched in } \\
\text { TDR/Fiocruz meeting in Rio; } \\
\text { clone CL-Brener is selected as model } \\
\text { organism }\end{array}$} \\
\hline $\begin{array}{l}\text { 1996: randomised and controlled field } \\
\text { trials of treatment with benznidazol } \\
\text { conducted in young patients; } \\
\text { the Southern Cone Initiative } \\
\text { progresses towards interruption of } \\
\text { transmission through vector } \\
\text { elimination }\end{array}$ & $\begin{array}{l}\text { First time demonstration of efficacy } \\
\text { of benznidazol in the reduction of } \\
\text { seroreactivity titers and prevention } \\
\text { of chronic cardiac lesions }\end{array}$ & $\begin{array}{l}\text { (Schmunis et al. 1996, De } \\
\text { Andrade et al. 1996) }\end{array}$ \\
\hline $\begin{array}{l}\text { 1997: meeting of the Andean Countries } \\
\text { Initiative, Bogotá, Colombia (February); } \\
\text { meeting of the Central American } \\
\text { Countries Initiative, Tegucigalpa, } \\
\text { Honduras (October) }\end{array}$ & $\begin{array}{l}\text { Detailed plan of activities and } \\
\text { budget were devised and elimination } \\
\text { of transmission foreseen in } 2010\end{array}$ & \\
\hline $\begin{array}{l}\text { 1997: an analysis of the cost-effectiveness } \\
\text { and cost-benefit of the Chagas Disease } \\
\text { Control Programme conducted by the } \\
\text { Ministry of Health of Brazil and PNUD } \\
\text { showed that for each US\$ } 37.30 \text { spent } 1 \\
\text { DALY was gained and that for each } \\
\text { dollar spent on prevention almost US\$ } \\
17.50 \text { were saved }\end{array}$ & $\begin{array}{l}\text { The study places the program and its } \\
\text { activities in the category of interventions } \\
\text { with a very high cost-effectiveness } \\
\text { and indicates that it is a health } \\
\text { investment with good return; } \\
\text { the study also showed that the decline in } \\
\text { Chagas disease infection rates was due to } \\
\text { the preventive activities and not due to } \\
\text { general improvement in life conditions }\end{array}$ & (Akhavan 1997) \\
\hline $\begin{array}{l}\text { 1998: Latin American meeting scheduled } \\
\text { to take place in April at Fiocruz } \\
\text { headquarters in Rio de Janeiro in order } \\
\text { to discuss and adopt a therapeutic } \\
\text { protocol to treat young patients in } \\
\text { order to prevent the development of } \\
\text { chronic cardiac lesions }\end{array}$ & & (De Andrade et al. 1996) \\
\hline
\end{tabular}

one year time, new questions arose and there was still an unfinished agenda at the end of the meeting. The 3rd meeting was planned, again in one year time, again in Caxambu, and again the participants themselves selected the organizers of the next meeting - and what follows is also history.

The Annual Meetings on Basic Research on Chagas Disease, which have run uninterruptedly all these years became a world-class scientific event (Marshall 1995) and a forum where scientists, research managers, policy makers and government authorities meet and discuss science and public health. From a round table discussion with ten participants, a huge, 700-people annual meeting became established (Table II).

At the same time, a very important partner came into being and provided much of the grounds needed for international collaboration: I do not hesitate to attribute a pivotal role to TDR in the building up of a critical mass of well trained and informed Latin American scientists interested in Chagas disease.

1984 saw the starting of the Annual Meetings on Applied Research on Chagas Disease, which used to be held in Araxá and now moved to Uberaba, both cities also located in Minas Gerais and at a driving distance from Caxambu, so that one can attend both meetings which take place 1-2 days apart.

These Annual Meetings, in Caxambu and Uberaba, became a major driving force for research in Latin America - and much more. They turned into an annual forum of debates and policy-making. Three examples will illustrate how they helped to transform research into action:

- Sensitizing scientific and public opinion: during the military regimen Brazil decided to buy from France some 15 Mirage air fighters; Zigman Brener presented careful calculations showing that if instead of buying 15 planes we 
TABLE II

Caxambu meetings, 1974-1998

\begin{tabular}{|c|c|c|c|c|c|c|c|c|c|c|c|}
\hline$\#$ & Organizers & Mem IOC & Year & C\&RT & BI & BQ & IM & QT & VE & PZ & Total \\
\hline 1 & J Ferreira Fernandes & - & 1974 & 0 & 0 & 0 & 0 & 0 & 0 & 0 & 0 \\
\hline 2 & Z Brener & - & 1975 & 0 & 30 & 0 & 0 & 0 & 0 & 0 & 30 \\
\hline 3 & FS Cruz/W Leon & - & 1976 & 0 & 50 & 0 & 0 & 0 & 0 & 0 & 50 \\
\hline 4 & W Colli/EP Camargo & - & 1977 & 3 & 30 & 33 & 27 & 0 & 0 & 0 & 93 \\
\hline 5 & CM Morel & - & 1978 & 10 & 51 & 43 & 40 & 0 & 0 & 0 & 144 \\
\hline 6 & C Chagas Filho & - & 1979 & 15 & 40 & 35 & 36 & 0 & 13 & 0 & 139 \\
\hline 7 & W Souza/M Barcinski & - & 1980 & 9 & 60 & 40 & 58 & 13 & 24 & 0 & 204 \\
\hline 8 & LRRG Travassos & - & 1981 & 12 & 52 & 36 & 70 & 7 & 19 & 0 & 196 \\
\hline 9 & AU Krettli & - & 1982 & 13 & 76 & 41 & 87 & 4 & 27 & 0 & 248 \\
\hline 10 & H Krieger & - & 1983 & 8 & 67 & 60 & 75 & 18 & 20 & 0 & 248 \\
\hline 11 & RR Santos & - & 1984 & 5 & 69 & 53 & 86 & 14 & 52 & 0 & 279 \\
\hline 12 & DF Almeida & - & 1985 & 8 & 67 & 50 & 73 & 14 & 46 & 37 & 295 \\
\hline 13 & B Zingales/MJM Alves & Vol 81 Suppl. 1 & 1986 & 1 & 68 & 63 & 76 & 16 & 35 & 38 & 297 \\
\hline 14 & S Coutinho/MP Deane & Vol 82 Suppl. 1 & 1987 & 12 & 68 & 51 & 111 & 22 & 33 & 62 & 359 \\
\hline 15 & TL Kipnis/WD Silva & Vol 83 Suppl. 1 & 1988 & 68 & 84 & 79 & 122 & 18 & 33 & 62 & 466 \\
\hline 16 & E Garcia/S Goldenberg & Vol 84 Suppl. 2 & 1989 & 1 & 58 & 48 & 60 & 15 & 42 & 63 & 287 \\
\hline 17 & E Chiari/J Ramalho-Pinto & Vol 85 Suppl. 1 & 1990 & 0 & 62 & 58 & 58 & 11 & 32 & 66 & 287 \\
\hline 18 & I Abrahamson/RA Mortara & Vol 86 Suppl. 1 & 1991 & 41 & 67 & 76 & 78 & 13 & 31 & 56 & 362 \\
\hline 19 & T Souto Padrón/E Rondinelli & Vol 87 Suppl. 2 & 1992 & 35 & 56 & 73 & 80 & 19 & 37 & 59 & 359 \\
\hline 20 & $\begin{array}{l}\text { Z Brener/B Zingales/E Chiari/ } \\
\text { I Roitman/S Goldenberg }\end{array}$ & Vol 88 Suppl. 1 & 1993 & 43 & 63 & 97 & 115 & 25 & 44 & 82 & 469 \\
\hline 21 & N Yoshida/LM Floeter-Winter & Vol 89 Suppl. 1 & 1994 & 43 & 55 & 92 & 109 & 22 & 37 & 94 & 452 \\
\hline 22 & MNL Meirelles/J Scharfstein & Vol 90 Suppl. 1 & 1995 & 56 & 58 & 84 & 98 & 33 & 46 & 117 & 492 \\
\hline 23 & A K Cruz/JF Silveira & Vol 91 Suppl. 1 & 1996 & 58 & 55 & 110 & 133 & 49 & 78 & 96 & 579 \\
\hline 24 & AK Cruz/JF Silveira & Vol 92 Suppl. 1 & 1997 & 68 & 128 & 148 & 135 & 31 & 91 & 0 & 601 \\
\hline 25 & $\begin{array}{l}\text { A Barral, E Carvalho, M Barral- } \\
\text { Neto, W de Souza }\end{array}$ & Vol 93 Suppl. 2 & 1998 & 82 & 126 & 143 & 173 & 53 & 89 & 0 & 666 \\
\hline \multicolumn{2}{|c|}{ Total } & & & 591 & 1540 & 1513 & 1900 & 397 & 829 & 832 & 7602 \\
\hline
\end{tabular}

\section{Evolution af Annual Meetings on Basic Research in Chagas Disease}

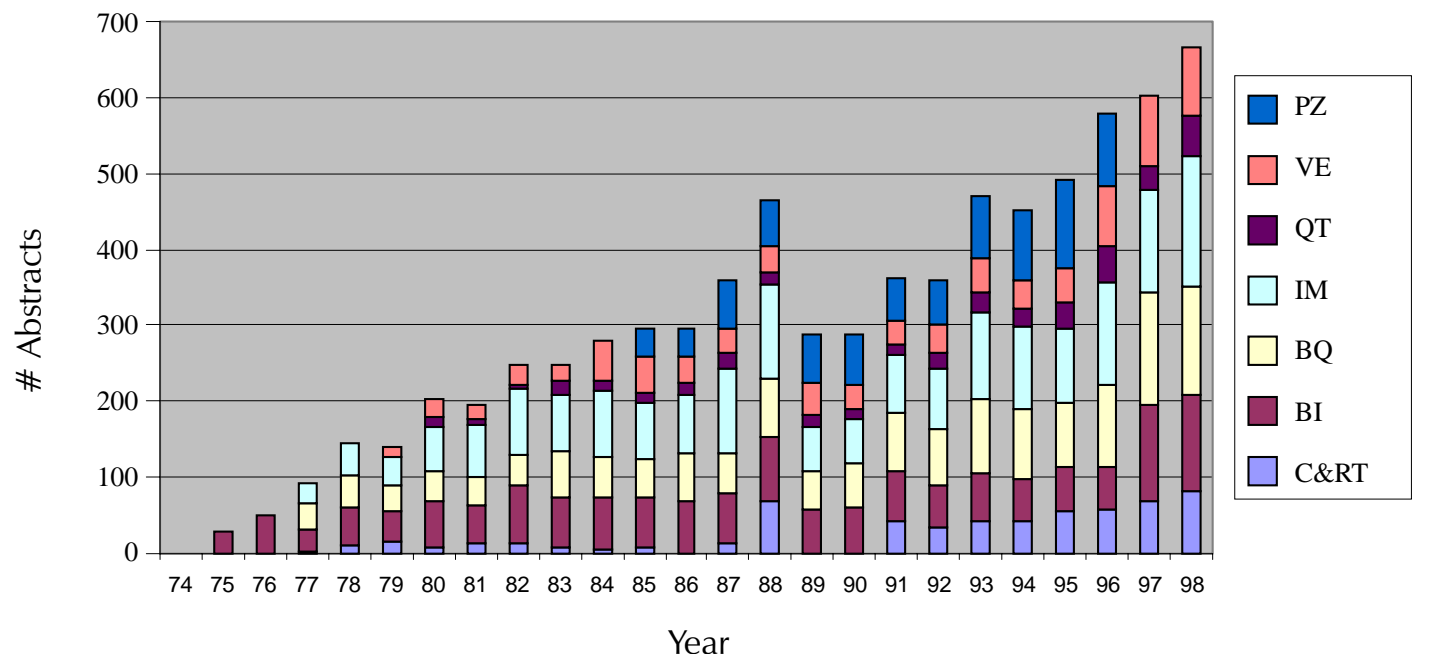

The meetings of 1974 (1st) and 1979 (6th) were held in Rio de Janeiro; all the others in Caxambu, MG. Abbreviations: Mem IOC: Memórias do Instituto Oswaldo Cruz; PZ: protozoology; VE: vectors; QT: chemotherapy; IM: immunology; BQ: biochemistry; BI: biology; C\&RT: conferences, mini-conferences \& round tables. 
bought 13 , the savings would be sufficient to carry out a nation-wide vector control program which could stop transmission of the disease, as it had been demonstrated in the Bambuí field station. At the same moment he also showed us numbers on how many new cases of Chagas disease could have been avoided if such a program had started immediately after the 1948 work of Dias and Pellegrino demonstrating the efficiency of insecticides against domiciliated vectors (Dias \& Pellegrino 1948). These data became information in the brain and mouth of the participants - although all the planes were finally bought and no national program started, we all realized that something could be done if we could fight more efficiently towards a higher political priority for public health problems;

- Influencing the government: in 1979-70 years of the discovery of Chagas disease - it was decided to have the meeting in Rio de Janeiro, to transform it on an international event and to have the President of the Republic at the inauguration ceremony. Prof. Carlos Chagas Filho, the son of Carlos Chagas and himself one of the most highly respected scientists in Brazil, was asked to organize the event. As the result of this strategy, at the end of the meeting funds could be secured for the starting of a pilot vector control programme against Chagas disease;

- Stimulating leadership formation and decision-making: the turning point came years later, when one of our Caxambu fellow scientists, Dr João Carlos Pinto Dias, became the Director of the Chagas Disease Division at the Ministry of Health, when the military regimen ended. The transmutation of researchers into policy-makers, as in his case, opened new perspectives in Chagas disease control and radically changed the priority-setting mechanisms at the Ministry of Health. Finally, research was in action.

As there are several ways of telling one story, my perception is surely not the only valid one. But it would be hard to analyze the $1975-1990$ period and not share similar thoughts. Therefore:

Lesson to take home, \#3 - Health researchers must meet, share their findings, doubts and uncertainties, discuss the constraints on their work and on public health issues, raise public consciousness and eventually become policy-makers, a very efficient shortcut to the long road needed to transform research into action.

\section{THE NEXT RESEARCH AGENDAS}

[For a overview on the trends in Chagas disease research see Moncayo 1994 and Anonymous 1997].

\section{The "post control" research agenda}

We are now at a crossroads in relation to research in Chagas disease, and tension is mounting due to opposing views among researchers, health authorities and policy makers.

On one extreme there are those who think that Chagas disease is well under control, that the existing tools have proven their efficacy and therefore no further effort or resources should be spent in this field. Their arguments seem to be so more valid as the burden of other diseases or unhealthy conditions is skyrocketing in the Third World due to epidemiological and demographic transitions. In fact it is common knowledge that in several developing countries the burden of infectious and parasitic diseases is now being diluted by the toll of chronic and degenerative illnesses, aging and violence and also by emerging and re-emerging diseases, such as Aids (Godal et al. 1996).

On the other side there are those that insist that the threat from Chagas disease is as serious as it has ever been, that reinfestation of the houses will happen soon in most of the places and that we are in real danger of spoiling all the efforts of the last years by underestimating the adversary.

History has shown us how complex this kind of dilemma can be, and one could pick up whichever example fits better in one's own position, forgetting those that point in the opposite direction. Underestimating the possibility of resurgence of "controlled" diseases can be a fatal mistake (remember tuberculosis control and malaria eradication). On the other hand, several announced apocalypses did not materialize.

I do not think I innovate by saying that one should avoid the extreme scenarios. Although it is true that official data demonstrate the progress made in the control of Chagas disease (Anonymous 1997), particularly in relation to its vectorial transmission which has been virtually eliminated from Brazil (Anonymous 1996), it is also true that this disease still remains as a scourge in large regions of Latin America (Schmunis 1994). It is therefore imperative that control programmes against Chagas disease in these areas receive high priority at the local, national and international levels (Schmunis 1997), for as it was established by Carlos Chagas and Emmanuel Dias long ago, more than technical innovations, the final overcoming of human Chagas disease involves mainly political will and social responsibility (Dias 1997).

Although the persistence of the disease is in part a consequence of this lack of political will to adopt available and proven control tools, e.g. in blood banks, there is undoubtedly the need for a focused, operational research agenda addressing additional key issues related to control activities. 
In the words of João Carlos Pinto Dias, it must be remembered that research must be a continuous feature of the surveillance phase, because the program involves such a close relation between local communities, technical support groups and the rapidly changing environment (Dias 1997). This is particularly true for the Andean and Central American countries, where the vectors of Chagas disease are not strictly domiciliary (Division of Control of Tropical Diseases 1996). This research agenda will have to be a rather different one from that of the heroic old times of Lassance, where Chagas disease was discovered, and Bambuí, where the control tools against domiciliated triatomines were first tried. This new agenda will have to focus on nondomiciliated vectors, their systematics, distribution, evolution, genetics, behaviour and population biology (Anonymous 1997). In addition, it should also address topics such as: monitoring of insecticide resistance; diagnostics in areas of low disease prevalence; mathematical modelling and epidemiological impact of control activities (Schofield 1994, Schofield \& Dujardin 1997).

\section{The unfinished research and development (R\&D) agenda}

Even if Chagas disease is eliminated as a public health problem from all Latin American countries, we still would have to cope with the problem of millions of chronically-infected people of the region. Recent data indicate that the development of chronic lesions, which seem to be mediated in a large extent by autoimmune mechanisms (Teixeira et al. 1975, Schmuñis 1987, Cunha-Neto et al. 1995, 1996), seems to depend on the persistence of parasite infection (Jones et al. 1993, Higuchi et al. 1993, Brandariz et al. 1996, Vago et al. 1996, Levin 1996). Therefore the need to find appropriate new drugs, or new protocols with existing drugs, that can be used in the treatment of Chagas disease in order to prevent the development of serious clinical forms (De Andrade et al. 1996, Urbina et al. 1996, Luquetti 1997). As a corollary, one has to define reliable criteria for the cure of these patients, ideally based on the actual determination of parasite load before and after treatment (Britto et al. 1995).

Another yet unsolved problem in clinical studies on Chagas disease is the question of possible relationships between the different clinical forms, their morbidity and the different parasite strains (Montamat et al. 1996). The recent demonstration that there are two major phylogenetic lineages of T. cruzi (Souto et al. 1996) will surely stimulate new approaches to this old question (Brener 1973, 1977). In addition, it has brought new perspectives for those interested in molecular epidemiological studies of Chagas disease (Miles et al. 1977, Mattei et al. 1977, Morel et al. 1980, Tibayrenc et al. 1986, Britto et al. 1995, Oury et al. 1997)

\section{An agenda for the future}

The ideal strategy against tropical diseases, synthesized in the TDR motto "investigate, eliminate, eradicate", is unfortunately inapplicable to Chagas disease. Due to its zoonotic nature, one can think of elimination of this disease as a public health problem, but eradication of the parasite is not a feasible goal. There is therefore the need for a long-term research agenda for the future, aiming at the development of new prevention and control tools, such as efficient vaccines and safer drugs.

In my vision the road to the future will be strongly based on what is being called the new (molecular) biology, based on the information generated by the various ongoing genome projects, addressing the human, pathogen and vector genomes. Progress in this area has been truly remarkable, with the area now known as "Genomics" evolving from "Structural-" to "Functional-" and "Evolutionary Genomics" (Duboule 1997). The results already accumulated are good enough to allow us foresee how biological research will be in the so-called post-genome era (Tilghman 1997). It is hoped that the T. cruzi genome project will allow a better understanding of the parasite biology and its interaction with the vertebrate and invertebrate hosts, as well as the development of new control tools such as vaccines and therapeutic approaches based on the molecular structure of new targets and rational drug design.

Developing countries are already participating in these efforts, in view of the benefits one can expect from these projects and despite the immense challenges to be faced (Pena 1996, Zingales et al. 1997a,b). The T. cruzi genome project, which matured in several meetings in 1993 and 1994 and was officially launched in 1994 in a TDR-Fiocruz co-sponsored meeting held at Fiocruz's headquarters in Rio de Janeiro, is now well under way through the concerted action of more than 20 laboratories, most of them in the South (Cano et al. 1995, Zingales et al. 1997a,b,c, Brandão et al. 1997, Santos et al. 1997, Ferrari et al. 1997, Degrave et al. 1997a,b).

The research agenda for the future will probably be tackled in a very different way from that used by the founding fathers of Chagas disease research. The new biology - technology intensive and addressing complex problems - has to be carried out through networks and international collaboration, and will have to rely on the newest communication and information technology (Degrave et al. 1997b). 


\section{FINAL COMMENTS}

The TDR motto "investigate, eliminate, eradicate" carries in it the notion of different stages of the never-ending fight against diseases. Our microbial enemies and their vectors are smart and able to develop different strategies for coping with our weapons (Garrett 1994, Anonymous 1994, Wilson et al. 1994, Marques 1995, Schwartz \& Bryan 1996, LeDuc 1996, Patz et al. 1996). We have no choice but to be imaginative, flexible and devoid of prejudices in the selection of the new priorities that will shape our next research agendas.

As we move forward in the direction of Chagas disease elimination, entering into a "post-control" era, we will face new and unknown challenges, and the lessons of history will become less and less useful. This brings us to the last lesson to take home:

Lesson to take home, final - After a given point there are no lessons to take home - we will have to rely on further research to shape the road to the future.

In other words, "Caminante, no hay camino, se hace camino al andar" (Antonio Machado, Spanish, 1875-1939).

\section{"Caminante, son tus huellas} el camino e nada más; caminante, no hay camino se hace camino al andar. Al andar se hace camino, y al volver la vista atrás se ve la senda que nunca se há de volver a pisar.

Caminante, no hay camino, sino estelas en la mar."

\section{"Voyageur, le chemin}

sont les traces de tes pas, c'est tout; voyageur Il n'y a pas de chemin, le chemin se fait en marchant.

Le chemin se fait en marchant et quand on tourne les yeux en arrière on voit le sentier que jamais on ne doit à nouveau fouler Voyageur, il n'est pas de chemin. rien que sillages sur la mer"

Antonio Machado: Campos de Castilla - Provérbios y Cantares (1907-1917). French translation by Sylvie Léger and Bernard Sesé, Gallimard, 1973.

\section{ACKNOWLEDGEMENTS}

To Prof W Lobato Paraense, Dr CJ Schofield, Dr A Moncayo and Dr O Fernandes for their most helpful comments and suggestions and to the Fiocruz's Units Casa de Oswaldo Cruz and Biblioteca de Manguinhos for the access to historical documents and photographs.

\section{REFERENCES}

Akhavan D 1997. Análise de custo-efetividade do Programa de Controle da Doença de Chagas no Brasil. Relatório final. Fundação Nacional de Saúde, Ministério da Saúde, Brasilia.

Anonymous 1994. Addressing Emerging Infectious Disease Threats: A Prevention Strategy for the United States, US: CDC Atlanta, GA.

Anonymous 1995. Tropical Disease Research - Progress 1975-94 Highlights 1993-94 (Twelfth Programme Report), TDR Geneva.

Anonymous 1996. Division of Control of Tropical Diseases. Progress Report 1996, World Health Organization, Geneva.

Anonymous 1997. Chagas disease, p. 112-123. In World Health Organization, Tropical Disease Research: Progress 1995-96, Thirteenth Programme Report, TDR Geneva.

Anonymous 1997. The World Health Report 1997. Conquering suffering, enriching humanity, World Health Organization, Geneva.

Aragão HB 1950. Noticia histórica sobre a fundação do Instituto Oswaldo Cruz. Mem Inst Oswaldo Cruz 48: $1-50$.

Benchimol J 1990. Manguinhos do Sonho à Vida. A Ciência na Belle Époque, Casa de Oswaldo Cruz, Fiocruz, Rio de Janeiro.

Benchimol J, Teixeira LA 1993. Cobras, Lagartos \& outros Bichos: Uma História Comparada dos Institutos Oswaldo Cruz e Butantan, UFRJ, Rio de Janeiro.

Brandariz S, Schijman A, Vigliano C, Viotti R, Levin M 1996. Role of parasites in the pathogenesis of Chagas' cardiomyopathy - Reply. Lancet 347: 914914.

Brandão A, Urmenyi T, Rondinelli E, Gonzalez A, Miranda AB, Degrave W 1997. Identification of transcribed sequences (ESTs) in the Trypanosoma cruzi genome project. Mem Inst Oswaldo Cruz 92: 863866.

Brener Z 1973. Biology of Trypanosoma cruzi. Ann Rev Microbiol 27: 347-382.

Brener Z 1977. Intraspecific Variations in Trypanosoma cruzi: Two Types of Parasite Populations Presenting Distinct Characteristics, Pan American Health Organization, Washington.

Brener Z 1989. A descoberta. Mem Inst Oswaldo Cruz 84: 1-6.

Britto C, Cardoso MA, Ravel C, Santoro A, BorgesPereira J, Coura JR, Morel CM, Wincker P 1995a. Trypanosoma cruzi: Parasite detection and strain discrimination in chronic chagasic patients from Northeastern Brazil using PCR amplification of kinetoplast DNA and nonradioactive hybridization. Exp Parasitol 81.

Britto C, Cardoso MA, Vanni CMM, HasslocherMoreno A, Xavier SS, Oelemann W, Santoro A, Pirmez C, Morel CM, Wincker P 1995b. Polymerase chain reaction detection of Trypanosoma cruzi in human blood samples as a tool for diagnosis and treatment evaluation. Parasitology 110: 241-247.

Brumpt E 1914. O xenodiagnóstico. Aplicação ao diagnóstico de algumas infecções parasitárias e, em 
particular, à tripanosomose de Chagas. An Paul Med Cirurg 3: 97-102.

Camargo ME, Silva GR, Castilho EA, Silveira AC 1984. Inquérito sorológico de prevalência da infecção chagásica no Brasil, 1975-1980. Rev Inst Med Trop São Paulo 26: 192-204.

Cano MI, Gruber A, Vazquez M, Cortés A, Levin MJ, González A, Degrave W, Rondinelli E, Zingales B, Ramirez JL, Alonso C, Requena JM, Da Silveira JF 1995. Molecular karyotype of clone CL Brener chosen for the Trypanosoma cruzi Genome Project. Mol Biochem Parasitol 71: 273-278.

Chagas C 1909. Nova tripanozomiaze humana. Estudos sobre a morfolojia e o ciclo evolutivo do Schizotrypanum cruzi n.gen., n.sp., ajente etiolojico de nova entidade morbida do homem - Ueber eine neue Trypanosomiasis des Menschen. Studien über Morphologie und Entwicklungszyklus des Schizotrypanum cruzi $n$. gen., n. sp., Erreger einer neuen Krankheit des Menschen. Mem Inst Oswaldo Cruz 1: $159-218$.

Chagas Filho C 1993. Meu Pai, Casa de Oswaldo Cruz, Fiocruz, Rio de Janeiro.

Comission on Health Research for Development 1990. Health Research: Essential Link to Equity in Development, Oxford University Press, New York.

Coura JR 1997. Síntese histórica e evolução dos conhecimentos sobre a doença de Chagas, p. 469486. In JCP Dias, JR Coura (eds), Clínica $e$ Terapêutica da Doença de Chagas. Uma Abordagem Prática para o Clínico Geral. Editora Fiocruz, Rio de Janeiro.

Cunha-Neto E, Coelho V, Guilherme L, Fiorelli A, Stolf N, Kalil J 1996. Autoimmunity in Chagas' disease Identification of cardiac myosin-B13 Trypanosoma cruzi protein crossreactive $\mathrm{T}$ cell clones in heart lesions of a chronic Chagas' cardiomyopathy patient. J Clin Invest 98: 1709-1712.

Cunha-Neto E, Duranti M, Gruber A, Zingales B, De Messias I, Stolf N, Bellotti G, Patarroyo ME, Pilleggi F, Kalil J 1995. Autoimmunity in Chagas disease cardiopathy: Biological relevance of a cardiac myosin-specific epitope crossreactive to an immunodominant Trypanosoma cruzi antigen. Proc Natl Acad Sci USA 92: 3541-3545.

Da Fonseca filho O 1973. Doença de Chagas, p. 43-66. In Anonymous Oswaldo Cruz Monumenta Historica - Tomo II: A Escola de Manguinhos, São Paulo.

Davies AM, Mansourian B 1992. Research strategies for health, Lewinston, NY, Published on behalf of the World Health Organization by Hogrefe \& Huber Publishers.

De Andrade ALSS, Zicker F, De Oliveira RM, Silva SAE, Luquetti A, Travassos LR, Almeida IC, De Andrade SS, De Andrade JG, Martelli CMT 1996. Randomised trial of efficacy of benznidazole in treatment of early Trypanosoma cruzi infection. The Lancet 348: 1407-1413.

Deane MP, Jansen AM, Lenzi HL 1984. Vertebrate and invertebrate cycles in the same mammal host the opossum Didelphis marsupialis. Mem Inst Oswaldo Cruz 79: 513-515.

Degrave W, Levin MJ, Franco-da-Silveira J, Morel CM 1997a. Parasite genome projects and the Trypanosoma cruzi genome initiative. Mem Inst Oswaldo Cruz 92: 859-862.

Degrave W, Miranda AB, Amorim A, Brandão A, Aslett M, Vandeyar M 1997b. TcruziDB, an integrated database, and the WWW Information Server for the Trypanosoma cruzi genome project. Mem Inst Oswaldo Cruz 92: 805-809.

Delana M, Chiari E, Morel CM, Gonçalves AM, Romanha AJ 1996. Characterization of 2 isolates of Trypanosoma cruzi obtained from the patient Berenice, the first human case of Chagas disease described by Chagas, Carlos in 1909. Parasitol Res 82: 257-260.

Delaporte F 1995. Chagas, a lógica e a descoberta. Chagas, the logic and the discovery. Historia, Ciências, Saúde - Manguinhos 1: 39-53.

Dias E, Pellegrino J 1948. Alguns ensaios com o gammexane no combate aos transmissores da doença de Chagas. Brasil Médico 62: 185-191.

Dias E 1918. O Instituto Oswaldo Cruz: Resumo Histórico (1899-1918), Manguinhos, Rio de Janeiro.

Dias JCP 1986. The Brazilian Chagas' disease control programme in 1986. Rev Soc Bras Med Trop 19: 129-133.

Dias JCP 1987. Control of Chagas disease in Brazil. Parasitol Today 3: 336-341.

Dias JCP 1997. Present situation and future of human Chagas disease in Brazil. Mem Inst Oswaldo Cruz 92: 13-15.

Division of Control of Tropical Diseases 1996. Chagas disease: A disease whose days are numbered, World Health Organization, Geneva.

Duboule D 1997. The evolution of genomics (Editorial). Science 278: 555-555.

Ferrari I, Lorenzi H, Santos MR, Brandariz S, Requena JM, Schijman A, Vásquez M, Franco-da-Silveira F, Ben-Dov C, Medrano C, Ghío S, López Bergami P, Cano I, Zingales B, Urmenyi T, Rondinelli E, González A, Cortés A, Lopez MC, Thomas MC, Alonso C, Ramirez JL, Chiurrillo MA, Rangel-Aldao R, Brandão A, Degrave W, Perrot V, Saumier M, Billaut A, Cohen D, Le Paslier D, Levin MJ 1997. Towards the physical map of the Trypanosoma cruzi nuclear genome: Construction of YAC and BAC libraries of the reference clone $T$. cruzi CL Brener. Mem Inst Oswaldo Cruz 92: 843-852.

Garrett L 1994. The Coming Plague: Newly Emerging Diseases in a World Out of Balance, Farrar Straus Giroux, New York.

Godal T, Jamison DT, Tulloch J 1996. Investing in Health Research and Development. Report of the Ad Hoc Committee on Health Research Relating to Future Intervention Options, Geneva, Switzerland: World Health Organization (Document TDR/Gen/96.1).

Guerra F 1970. American trypanosomiasis. An historical and a human lesson. Am J Trop Med Hyg 73: 83-118.

Guerreiro C, Machado A 1913. Da reação de Bordet e Gengou na moléstia de Chagas como elemento diagnóstico. Nota prévia. Brasil Médico 27: 225-226.

Higuchi ML, Brito T, Reis MM, Barbosa A, Bellotti G, Pereira-Barreto AC, Pileggi F 1993. Correlation between Trypanosoma cruzi parasitism and myocar- 
dial inflamatory infiltrate in human chronic chagasic myocarditis: light microscopy and immunohistochemical findings. Card Pathol 2: 101-106.

Jansen AM, Madeira F, Carreira JC, Medina-Acosta E, Deane MP 1997. Trypanosoma cruzi in the opossum Didelphis marsupialis: A study of the correlations and kinetics of the systemic and scent gland infections in naturally and experimentally infected animals. Exp Parasitol 86: 37-44.

Jones EM, Colley DG, Tostes S, Lopes ER, Vnencakj CL, McCurley TYL 1993. Amplification of a Trypanosoma cruzi DNA sequence from inflammatory lesions in human chagasic cardiomyopathy. Am J Trop M ed Hyg 48: 348-357.

Kingman S 1991. South America declares war on Chagas disease. New Scientist 16.

Köberle F 1956. Patogênese dos megas. Rev Goiana Med 2: 101-110.

Köberle F, Nador E 1955. Etiologia e patogenia do megaesôfago no Brasil. Rev Paul Med 47: 89-107.

Kraus R, Maggio C, Rosenbusch F 1915. Bocio, cretinismo y enfermedad de Chagas. 1. Comunicación. Prensa Medica Argentina 2: 2-5.

Kraus R, Rosenbusch F 1919. Bocio, cretinismo y enfermedad de Chagas (segunda comunicación). Rev Inst Bacteriol, Buenos Aires 2: 224-230.

Lázzari JO 1994. Autonomic nervous system alterations in Chagas' disease: Review of the literature, p. 7296. In Chagas' Disease and the Nervous System, Pan American Health Organization, Washington.

LeDuc JW 1996. World Health Organization strategy for emerging infectious diseases. J Am Med Associ 275: 318-320.

Lenzi HL, Jansen AM, Deane MP 1984. The recent discovery of what might be a primordial escape mechanism for Trypanosoma cruzi. Mem Inst Oswaldo Cruz 79: 7-12.

Levin MJ 1996. In chronic Chagas heart disease, don't forget the parasite. Parasitol Today 12:415-416

Lewinsohn R 1979. The discovery of Trypanosoma cruzi and of American trypanosomiasis (foot-note to the history of Chagas's disease). Trans $R$ Soc Trop Med Hyg 73: 523.

Luquetti AO 1997. Etiological treatment for Chagas disease. Parasitol Today 13: 127-128.

Marques MB 1995. Doenças infecciosas emergentes no reino da complexidade: implicaçoes para as políticas científicas e tecnológicas (Emerging infeccious diseases in the realm of complexity:iImplications for scientific and technological policies). Cad Saúde Pública 11: 361-388.

Marshall E 1995. A deadly parasite spurs up-to-theminute biology. Science 267: 811-812.

Mattei DM, Goldenberg S, Morel CM, Azevedo HP, Roitman I 1977. Biochemical strain characterization of Trypanosoma cruzi by restriction endonuclease cleavage of kinetoplast DNA. FEBS Lett 74: 264-268.

Mazza S 1934. Casos agudos benignos de enfermedad de Chagas comprobados en la Provincia de Jujuy. MEPRA 17: 3-11.

Mazza S 1936. Nota sobre el primer centenar de formas agudas de la enfermedad de Chagas comprobadas en la República por la Misión de Estudios de
Patología Regional Argentina. Prensa Medica Argentina 23: 1979-1981.

Mazza S, Montana A, Benitez C, Juzin E 1936. Transmisión de "Schizotrypanum cruzi" al niño por leche de la madre con enfermedad de Chagas. MEPRA 28: 41-46.

Mello RC, Brener Z 1978. Tissue tropism of different Trypanosoma cruzi strains. J Parasitol 64: 475-482.

Miles MA 1996. New World trypanosomiasis, p. 192205. In FEG Cox, Illustrated History of Tropical Diseases, The Wellcome Trust, London.

Miles MA, Toyé JP, Oswald SC, Godfrey DG 1977. The identification by isoenzyme patterns of two distinct stock-groups of Trypanosoma cruzi circulating independently in a rural area of Brazil. Trans $R$ Soc Trop Med Hyg 71: 217-225.

Moncayo A, 1994. Recent trends in Chagas' disease research, p. 54-71. In Chagas' disease and the nervous system. Pan American Health Organization, Washington.

Moncayo A, Luquetti AO 1990. Multicentre double blind study for evaluation of Trypanosoma cruzi defined antigens as diagnostic reagents. Mem Inst Oswaldo Cruz 85: 489-495.

Montamat EE, D'Oro GMD, Gallerano RH, Sosa R, Blanco A 1996. Characterization of Trypanosoma cruzi populations by zymodemes: Correlation with clinical picture. Am J Trop Med Hyg 55: 625-628.

Morel CM, Chiari E, Camargo EP, Mattei DM, Romanha AJ, Simpson L 1980. Strains and clones of Trypanosoma cruzi can be characterized by restriction endonuclease fingerprinting of kinetoplast DNA minicircles. Proc Natl Acad Sci USA 77: 6810-6814.

Nussenzweig V, Sonntag R, Biancalana A, Freitas JLP, Amato Neto V, 1953. Ação da violeta de genciana sobre o $T$. cruzi in vitro: sua importância na esterilização do sangue destinado à transfusão. Rev Paul Med 42: 57-58.

Oliveira Filho AM 1988. Development of insecticide formulations and determination of dosage and application schedules to fit specific situations. Rev Argentina Microbiol 20 (Suppl.): 39-48.

Oury B, Dutrait N, Bastrenta B, Tibayrenc M 1997. Trypanosoma cruzi: Evaluation of a RAPD synapomorphic fragment as a species-specific DNA probe. J Parasitol 83: 52-57.

Patz JA, Epstein PR, Burke TA, Balbus MD 1996. Global climate change and emerging infectious diseases. JAMA 275: 217-223.

Pellegrino J 1953. A doença de Chagas em Minas Gerais. Esboço crítico dos trabalhos publicados até 1951. Mem Inst Oswaldo Cruz 51: 611-668.

Pena SDJ 1996. Third World participation in genome projects. Trends Biot 14: 74-77.

Perleth M 1997. Historical Aspects of American Trypanosomiasis (Chagas' Disease), Peter Lang, Frankfurt am Main.

Peterson DS, Wrightsman RA, Manning JE 1986. Cloning of a major surface-antigen gene of Trypanosoma cruzi and identification of a nonapeptide repeat. Nature 322: 566-568.

Prata A 1981. Carlos Chagas - Coletânea de Trabalhos Científicos, Universidade de Brasilia, Brasília. 
Raymond SU 1997. Global health collaboration: Organizing for a time of renewal, New York Academy of Sciences, New York.

Romaña C, Abalos JW 1948. Accion del "Gammexane" sobre los triatomideos. "Control" domiciliario. An Inst Med Regional, Tucuman 2: 95-106.

Salgado JA, Garcez PN, Oliveira CA, Gallizze J 1962. Revisão clínica atual do primeiro caso humano descrito de doença de Chagas. Rev Inst Med Trop São Paulo 4: 330-337.

Santos FD, Thielen EV, Medeiros A, Reis R, Souza F, 1996. Revisitando a Amazônia. Expedição aos Rios Negro e Branco Refaz Percurso de Carlos Chagas em 1913, Fiocruz, Rio de Janeiro.

Santos MRM, Cano MI, Schijman A, Lorenzi H, Vásquez M, Levin MJ, Ramirez JL, Brandão A, Degrave W, Franco-da-Silveira F 1997. The Trypanosoma cruzi genome project: Nuclear karyotype and gene mapping of clone CL Brener. Mem Inst Oswaldo Cruz 92: 821-828.

Schmunis GA 1994. American trypanosomiasis as a public health problem, p. 3-29. In Chagas' Disease and the Nervous System, Pan American Health Organization, Washington.

Schmunis GA, 1997. Tripanossomíase Americana: seu impacto nas Américas e perspectivas de eliminação, p. 11-23. In JCP Dias \& JR Coura (eds), Clínica e Terapêutica da Doença de Chagas: Uma Abordagem Prática para o Clínico Geral. Fiocruz, Rio de Janeiro.

Schmunis GA, Zicker F, Moncayo A 1996. Interruption of Chagas' disease transmission through vector elimination. Lancet 348: 1171-1171.

Schmuñis GA 1987. Autoimmunity in Chagas' disease. Mem Inst Oswaldo Cruz 82: 287-310.

Schofield CJ 1994. Triatominae: Biology \& Control, UK: Eurocommunica Publications, West Susses.

Schofield CJ, Dias JCP, 1996. Introduction and historical overview, p. 11-16. In CJ Schofield, JP Dujardin, J Jurberg (eds), Proceedings International Workshop on Population Genetics and Control of Triatominae, Santo Domingo de los Colorados, Ecuador, 24-28 Sep/95, INDRE, Mexico City.

Schofield CJ, Dujardin JP 1997. Chagas disease vector control in Central America. Parasitol Today 13: 141144.

Schwartz DA, Bryan RT 1996. Infectious disease pathology and emerging infections - Are we prepared? Arch Pathol Lab Med 120: 117-124.

Silveira AC 1985. O programa de controle da doença de Chagas no Brasil. Ann Soc Belge Med Trop 65: $137-$ 148.

Silveira AC, Rezende DF 1994. Epidemiologia e controle da transmissão vetorial da doença de Chagas no Brasil. Rev Soc Bras Med Trop 27: 11-22.

Souto RP, Fernandes O, Macedo AM, Campbell DA, Zingales B 1996. DNA markers define two major phylogenetic lineages of Trypanosoma cruzi. Mol Biochem Parasitol 83: 141-152.

Stepan N, 1976. Gênese e Evolução da Ciência Brasileira (Beginnings of Brazilian Science, Oswaldo Cruz
Medical Research and Policy), Artenova, Rio de Janeiro (Original edition in English by Science History Publications, New York, 1976).

Task Force on Health Research for Development 1991. Essential National Health Research: A strategy for action in health and human development, Geneva.

Teixeira A, Teixeira ML, Santos-Buch C 1975. The immunology of experimental Chagas' disease. IV. Production of lesions in rabbits similar to those of chronic Chagas' disease in man. Am J Pathol 80: 163-180.

Thielen EV, Alves FAP, Albuquerque MB, Santos RA, Weltman WL 1991. Science Heading for the Backwoods: Images of the Expeditions Conducted by the Oswaldo Cruz Institute Scientists to the Brazilian Hinterland - 1911/1913, Fiocruz, Rio de Janeiro.

Tibayrenc M, Ward P, Moya A, Ayala FJ 1986. Natural populations of Trypanosoma cruzi, the agent of Chagas disease, hava a complex multiclonal structure. Proc Nat Acad Sci USA 83: 115-119.

Tilghman SM 1997. Lessons learned, promises kept: A biologist's eye view of the genome project. Genome Research 6: 773-780.

Urbina JA, Payares G, Molina J, Sanoja C, Liendo A, Lazardi K, Piras MM, Piras R, Perez N, Wincker P, Ryley JF 1996. Cure of short- and long-term experimental Chagas' disease using D0870. Science 273: 969-971.

Vago AR, Macedo AM, Adad SJ, Reis DD, CorreaOliveira R 1996. PCR detection of Trypanosoma cruzi DNA in oesophageal tissues of patients with chronic digestive Chagas' disease. Lancet 348: 891-892.

Vianna G 1911. Contribuição para o estudo da anatomia patológica da moléstia de Carlos Chagas. Mem Inst Oswaldo Cruz 3: 276-300.

Wendel S, Brener Z, 1992. Historical aspects, p. 5-12. In S Wendel, Z Brener, ME Camargo \& A Rassi (eds), Chagas Disease (American Trypanosomiasis): Its Impact on Transfusion and Clinical Medicine. Soc Bras Hematol Hemoter, ISBT (Intern Soc Blood Transfusion).

Wilson ME, Levins R, Spielman A, 1994. Disease in Evolution: Global Changes and Emergence of Infectious Diseases, NY Acad Sciences, New York.

Zingales B, Pereira MES, Almeida KA, Umezawa ES, Nehme NS, Oliveira RP, Macedo A, Souto RP 1997a. Biological parameters and molecular markers of clone CL Brener - The reference organism of the Trypanosoma cruzi genome project. Mem Inst Oswaldo Cruz 92: 811-814.

Zingales B, Pereira MES, Oliveira RP, Almeida KA, Umezawa ES, Souto RP, Vargas N, Cano MI, Silveira JF, Nehme NS, Morel CM, Brener Z, Macedo A 1997b. Trypanosoma cruzi genome project: biological characteristics and molecular typing of clone CL Brener. Acta Trop (Basel) 68: 159-173.

Zingales B, Rondinelli E, Degrave W, Da Silveira JF, Levin M, Le Paslier D, Modabber F, Dobrokhotov B, Swindle J, Kelly JM, Asslund L, Hoheisel JD, Ruiz AM, Cazzulo JJ, Pettersson U, Frasch AC 1997c. The Trypanosoma cruzi genome initiative. Parasitol Today 13: 16-22. 